\title{
CINCO NOTAS SOBRE A MÚSICA E OS INSTRUMENTOS MUSICAIS POPULARES EM PORTUGAL
}

\section{FIVE NOTES ABOUT MUSIC AND POPULAR INSTRUMENTS IN PORTUGAL}

\author{
Domingos Morais \\ Instituto de Estudos de Literatura e Tradição \\ Universidade Nova de Lisboa \\ domingosmorais@gmail.com
}

\section{Resumo}

A Música e os instrumentos musicais populares portugueses, tais como os conhecemos hoje, são resultantes de um longo processo em que múltiplos contributos e influências aconteceram.

Os instrumentos musicais são, a par com a tradição oral, um dos aspectos mais fascinantes dos traços e marcas que as viagens dos portugueses espalharam pelos cinco continentes.

Em cinco Notas, pensadas para quem deseje conhecer a música do povo português, tentamos encontrar sentido no que por vezes parece desconexo, fruto do acaso e da sorte. Mas em que reconhecemos a vontade das comunidades e a persistência na sua transmissão mesmo quando em contra corrente de poderes laicos e religiosos.

1- Instrumentos musicais em Portugal que contam histórias de viagens e perseguições

2- Panorama Músico-Instrumental Popular Português - no séc. XIX / XX

Conferencia apresentada no dia 19 de outubro de 2016, como parte da programação do VII Encontro de Musicologia de Ribeirão Preto - A viola Caipira na universidade: o regional, o local e o universal. 


\section{3- Violas em Portugal - uma longa história}

\section{4- As Recolhas - ou os "sacos das cantigas"}

\section{5- Do gesto musical, gerador privilegiado de identidade cultural - ou de como se forma o sentimento de pertença consciente}

«Há que restituir ao povo a sua música. Há que restituir-tha por dever e por necessidade: por dever humano e por necessidade estética. Por dever humano, porque a música é um bem comum, uma riqueza que por todos deve ser partilhada, uma eucaristia que todos têm o direito de comungar; e por necessidade estética, porque, desde sempre, e sobretudo nas épocas de crise, a música se foi retemperar nas fontes vivas da arte popular do perigo que corria de se esterilizar no afinamento extremo dos meios técnicos e especulativismo das questões teóricas, com prejuizo da verdade, da força e da humanidade da sua mensagem»

Fernando Lopes-Graça (1941)2

\section{Instrumentos musicais em Portugal que contam histórias de viagens e perseguições ${ }^{3}$}

Os instrumentos musicais são, a par com a tradição oral, um dos aspectos mais fascinantes dos traços e marcas que as viagens dos portugueses espalharam pelos cinco continentes. A difusão de alguns e não de todos, as alterações introduzidas localmente nas técnicas de construção, a influência e miscigenação locais, constituem desafios que sem explicar totalmente o que terá acontecido ajudam a compreender a importância que as práticas culturais associadas à música tiveram

\footnotetext{
2 LOPES-GRAÇA, Fernando, 1941, "Sobre o conceito de música portuguesa", Seara Nova, $n^{\circ} 740-742$.

3 MORAIS, Domingos; Os Instrumentos Musicais e as Viagens dos Portugueses, Instituto de Investigação Científica Tropical / Museu de Etnologia, Lisboa, 1986.
} 
para as comunidades que as quiseram continuar. A par com a quase inexistente adopção de músicas e instrumentos de outros povos que parece não acompanhar a inegável capacidade de adaptação dos portugueses aos costumes e práticas de vida quotidiana com que tiveram maior contacto.

A dificuldade em encontrar nexo para o que por vezes é parcamente documentado por fontes fidedignas (iconográficas, documentais) é em parte devido a uma característica comum às práticas musicais, em que o sedimento deixado por cada época se mistura com a seguinte, podendo mesmo coexistirem repertórios muito diferentes, em territórios muito próximos, executados por comunidades que se conhecem mas decidem manter práticas diferenciadas.

Essa afirmação permanente da diferença, aliada a interditos decorrentes dos conflitos territoriais e religiosos são a trama que perturba quem pensa encontrar explicações simples e directas para a complexidade das manifestações culturais, em permanente mudança e deriva criativa ou de sobrevivencia das pessoas concretas que thes dão sentido.

E também o papel fundamental que a música desempenha em todos os momentos da vida das comunidades, servindo necessidades idênticas de expansão lúdica, amorosa, cerimonial e ritual mas com procedimentos e meios dramaticamente diferentes.

As tentativas de escrever a história a partir do que hoje podemos observar nas comunidades que continuam determinadas práticas musicais é sempre arriscada se não for muito rigorosa. Por vezes há que reconhecer não dispormos de informação suficiente para estabelecer ligações e influências, explicar escolhas e mudanças.

A Música e os instrumentos musicais populares portugueses, tais como os conhecemos hoje, são resultantes de um longo processo em que múltiplos contributos e influências aconteceram. Orlando Ribeiro é a fonte principal desta Nota que vai buscar ao seu estudo sobre a Formação de Portugal ${ }^{4}$ as linhas orientadoras que marcam a moderna historiografia em Portugal.

${ }^{4}$ RIBEIRO, Orlando; A Formação de Portugal. Instituto de Cultura e Língua Portuguesa, Lisboa, 1987. 
Do periodo anterior à romanização da Península lbérica, pouco sabemos sobre a música e dança de lberos e Celtas, e dos povos que chegavam do Mediterrâneo: Fenícios, Gregos e Cartagineses, no $1^{\circ}$ milénio antes de Cristo.

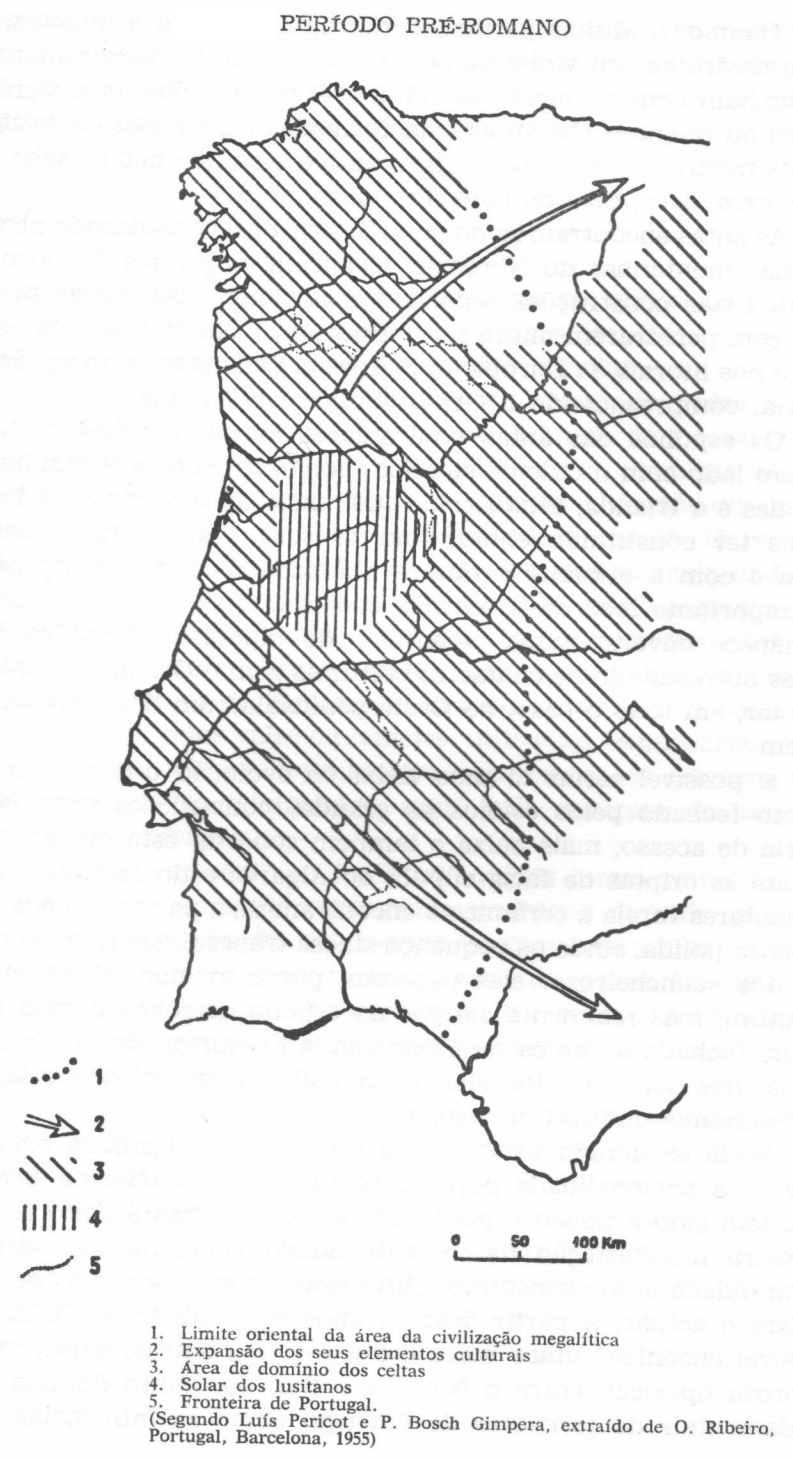


Estrabão, embora nunca tivesse estado na Península, dá-nos, com base em escritos anteriores que lev e compilou, a seguinte notícia referente aos Lusitanos (Sasportes, 1970)

\begin{abstract}
...mesmo bebendo, os homens põe-se a dançar, ora formando coros ao som da flauta e da trombeta, ora saltando cada um per si, a ver quem salta mais alto e mais graciosamente cai de joelhos. Na Bastetânia (povos do Sudeste) as mulheres dançam também, misturadas com os homens, cada uma tendo o seu par na frente, a quem de vez em quando dá a mão.
\end{abstract}

A Lusitânia era uma região cheia de contrastes. A fertilidade e a riqueza das suas costas, celebrada por vários autores, e onde habitavam ricos mercadores e grandes proprietários contrastava com a improdutividade e pobreza da sua zona interior, povoada por pastores e caçadores. A música devia ser um elemento festivo primordial nos actos da vida pública e privada dos ricos habitantes da costa, embora sejam escassas as referências em textos históricos (La Cuesta, 1983) 6 .

Diodoro de Sicília fala-nos de um tipo de dança muito rápida dançada pelos Lusitanos em tempo de paz. Tinham ainda danças e cantos de guerra que faziam antes das batalhas. Quando da morte de Viriato, os seus soldados fizeram danças guerreiras e cantaram os seus feitos, o que segundo La Cuesta, nos revela a existência de canções épicas de que apenas encontramos traços na tradição oral.

É lícito supor que, à semelhança do que acontece com outros povos pastoris, as flautas, tambores e talvez as gaitas de foles já se tocassem, mas não podemos ir mais longe nas suposições.

\footnotetext{
${ }^{5}$ SASPORTES, José, História da Dança em Portugal, Lisboa, 1970.

6 FERNANDES de la CUESTA, Ismael, Historia de la música española, I.Desde los origenes hasta el "Ars Nova, Madrid, 1983.
} 


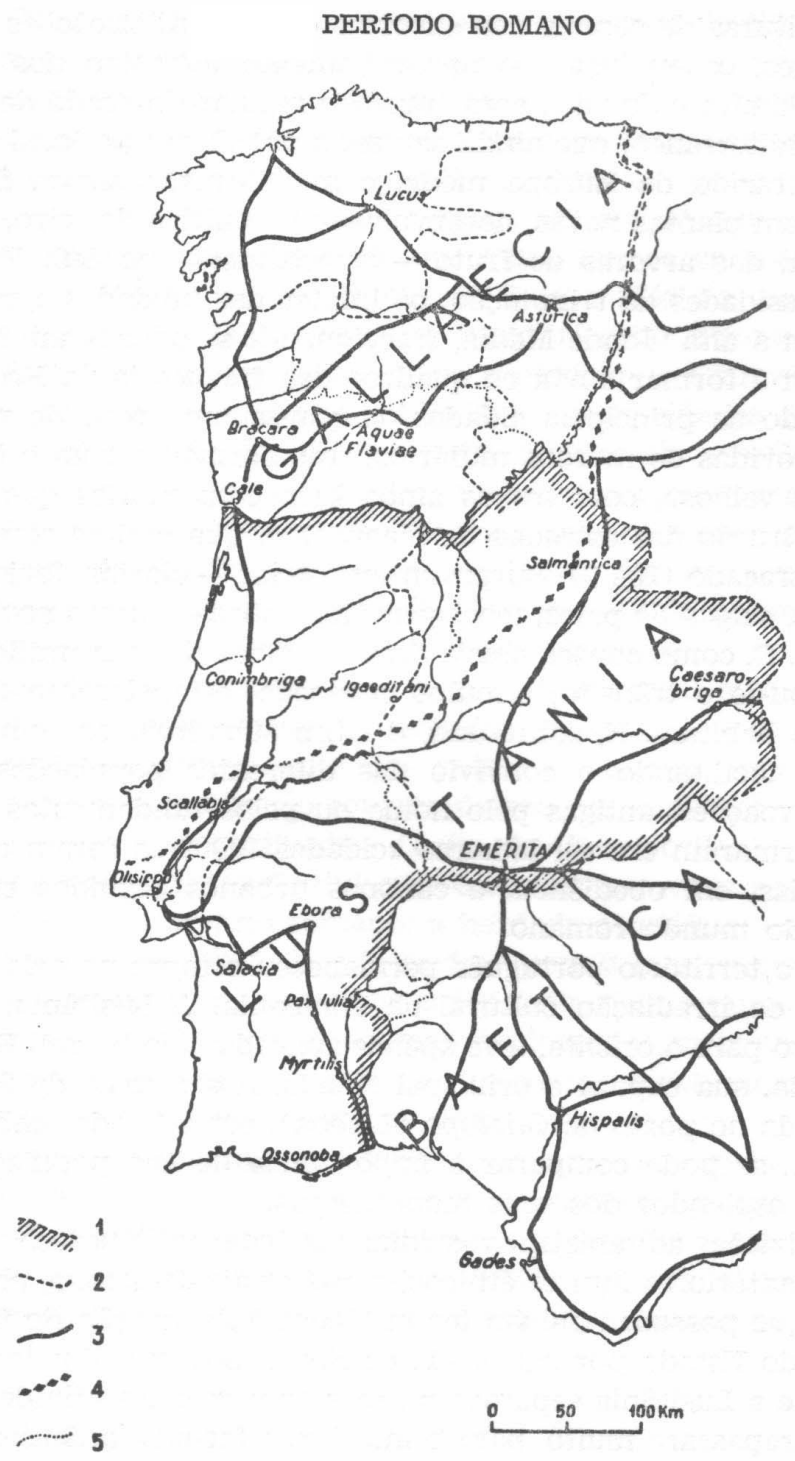

1. Limites da Lusitânia romana

2. Limites dos conventi

3. Vias principais

4. Limite aproximado do reino dos suevos

5. Fronteiras de Portugal

(Extraído de O. Ribeiro, Portugal, Barcelona, 1955) 
A romanização da Península, posterior às guerras com os Celtiberos e Lusitanos (154/137 A.C.) respeitou as crenças e o culto dos povos conquistados, dando no entanto lugar ao sincretismo próprio da colonização romana nas suas Províncias. A iconografia mostranos diversos instrumentos musicais que pela sua utilização funcional podemos agrupar em instrumentos de culto, da guerra, do trabalho, de cenas mitológicas, de teatro e espectáculo e de dança (Fleischaver, 1964) $)^{7}$.

La Cuesta refere que as comunidades judaicas estavam já na Península no período romano, embora sejam escassos e imprecisos os dados de que dispomos. Já é certa a sua presença nos primeiros anos do séc. IV, em que o Concílio de Elvira (Cranada) toma várias disposições relativas às relações entre cristãos e judeus. $\bigcirc$ culto cristão não era nas suas origens substancialmente diferente do judaico, tendo a sua separação progressiva conservado deste o canto e a recitação de salmos, junto com a leitura da Bíblia.

$1^{\circ}$ milénio da era cristã traz à Península, após a romanização, Alanos, Vândalos, Suevos e Visigodos, vindos do Norte e Centro da Europa. Com eles, e até ao início do domínio árabe em 711, temos por certo a constituição de um repertório litúrgico hispânico de grande exuberância, especialmente no tratamento dos vocalizos e dos seus numerosos aleluias (Hameline, 1982) ${ }^{8}$.

Este repertório, tal como os seus congéneres milanês e gaélico, resultou da fusão do rito romano com as tradições locais dos povos que se converteram ao catolicismo. Coexistindo com ele, os cultos agrários e solares, das forças naturais, das árvores, dos cereais, das águas, do fogo, dos mortos, etc., das festividades cíclicas dos povos lbéricos, que estão na origem de cânticos do ciclo solar, cantos ligados aos ritos de fertilidade, prantos e cantos fúnebres, sequências e tropos.

Os Mouros, que "nos quase oito séculos de permanência na Península não se fundiram racial nem culturalmente com os autóctones" (Matoso, 1979)9, trouxeram-nos instrumentos, músicas e danças que

7 FLEISCHAUER, G.- Etrurien und Rom, Leipzig, 1964.

8 HAMELINE, Jean-Ives - "Le chant grégorien" in Histoire de la Musique, ed.Bordas, 1982.

9 MATOSO, José - "Reconquista Cristã" in Dicionário de História de Portugal, Dir. de Joel Serrão, Porto, 1979. 
podemos encontrar nas iluminuras das Cantigas de Santa Maria e no Cancioneiro da Ajuda (sécs. XIII/XIV).

Com a Reconquista, ficaram a viver em relativa liberdade, podendo conservar os seus costumes, leis e religião (vd. Carta de Foral de Lisboa de 1170).

As comunidades judaicas, de há muito presentes na Península, viveram sob o domínio mouro e depois cristão. Diz-nos Viegas Guerreiro (1979) ${ }^{10}$ que eram "gente que mal se distinguia da cristã, que falava a mesma língua e vencida de iguais tentações", não admira que, "em períodos normais de paz, livres da excitação doutrinária, se tenham estabelecido com ela relações de simpatia e amizade com todas as consequências dai resultantes".

Oliveira Marques (1980)1" descreve-nos as festas em que participavam judeus e mouros, bailando, tangendo e tocando, como aconteceu quando do casamento do príncipe D. Afonso, filho de D. João || ( | 455- | 495), que ordenou que "... de tôdalas mourarias do reino, viessem às festas tôdolos mouros e mouras que soubessem bailar, tanger, cantar...".

Códice Calistino conta-nos como no séc. XII se encontravam em Santiago de Compostela peregrinos de toda a Europa, entre eles músicos tocando instrumentos das várias regiões de onde vinham. La Cuesta, embora nos alerte para um certo cuidado na leitura do Códice, que por vezes revela mais o que seria desejável, segundo o seu autor, do que a realidade histórica, transcreve o seguinte excerto:

Uns, cantavam acompanhando-se com pandeiretas, ...tíbias, ...físulas, ...trombetas,...sacabuchas, vihuelas, rotas britânicas e gaélicas, ...saltérios; outros, com toda a espécie de instrumentos, ficam sem dormir toda a noite, enquanto outros choram os seus pecados, outros recitam salmos. Ouvem-se todo o tipo de línguas ... e as canções dos alemães, ingleses, gregos e outras regiões e gentes.

10 Cuerreiro, M. Viegas - 'Mouros' e 'Judeus' in "Dicionário de História. de Portugal."op.cit. 1 MARQUES, A.O. - História de Portugal, Vol. I, $8^{\circledR}$ ed., Lisboa, 1980. 
As peregrinações e, embora limitadas no tempo, as cruzadas ( 1096/1270) contribuíram decisivamente para a difusão de instrumentos e repertórios musicais na Península lbérica.

As romarias, de âmbito mais restrito mas presentes em todo - País, eram (e são) peregrinações populares a um lugar tornado sagrado pela presença de um "santo", em locais de que por vezes há notícias anteriores à formação da nacionalidade (Sanchis, 19831) 12 Nelas se processava a troca entre os romeiros de "modas de vestuário, composições musicais ou coreográficas, talentos de poetas e contadores circulavam durante as romarias de uma aldeia para a outra, contribuindo para criar unidades culturais mais largas, se bem que em escala limitada".

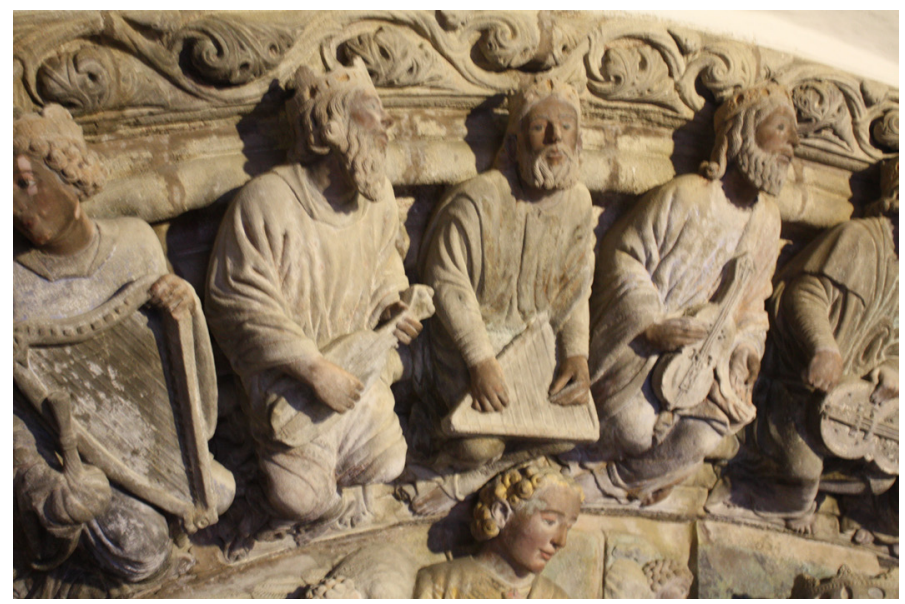

Dos instrumentos musicais de que temos notícia antes de 1500 em Portugal, referimos, nos cordofones sem braço a harpa, a lira, a rota, a cítara, o saltério e o monocórdio: nos cordofones com braço, o alaúde, a mandora, a bandurra, a baldosa, a cítola, a cedra, a guitarra e a vihuela; todos eram tocados com os dedos ou com plectro. Nos cordofones de corda friccionada, o arco, a giga, o arrabil mourisco, o rabel, a vihuela de arco e a sinfonia (sanfona) ${ }^{13}$.

\footnotetext{
12 SANCHIS, Pierre - Arraial, Festa de um Povo, Publicações D. Quixote, Lisboa, 1983.

13 Pórtico da Clória séc. XII - Catedral de Santiago de Compostela, Galiza (Foto de P. Lameiro, 20|4).
} 
Nos aerofones, as longas, trompas e charamelas. a exabeba (flauta transversal), o anafil, o albogue, a flauta, o odrezinho, a pípia, a gaita (de foles) e o orgão. Nos instrumentos de pele, o tambor, o pandeiro, o adufe, o atabal ou atabaque.
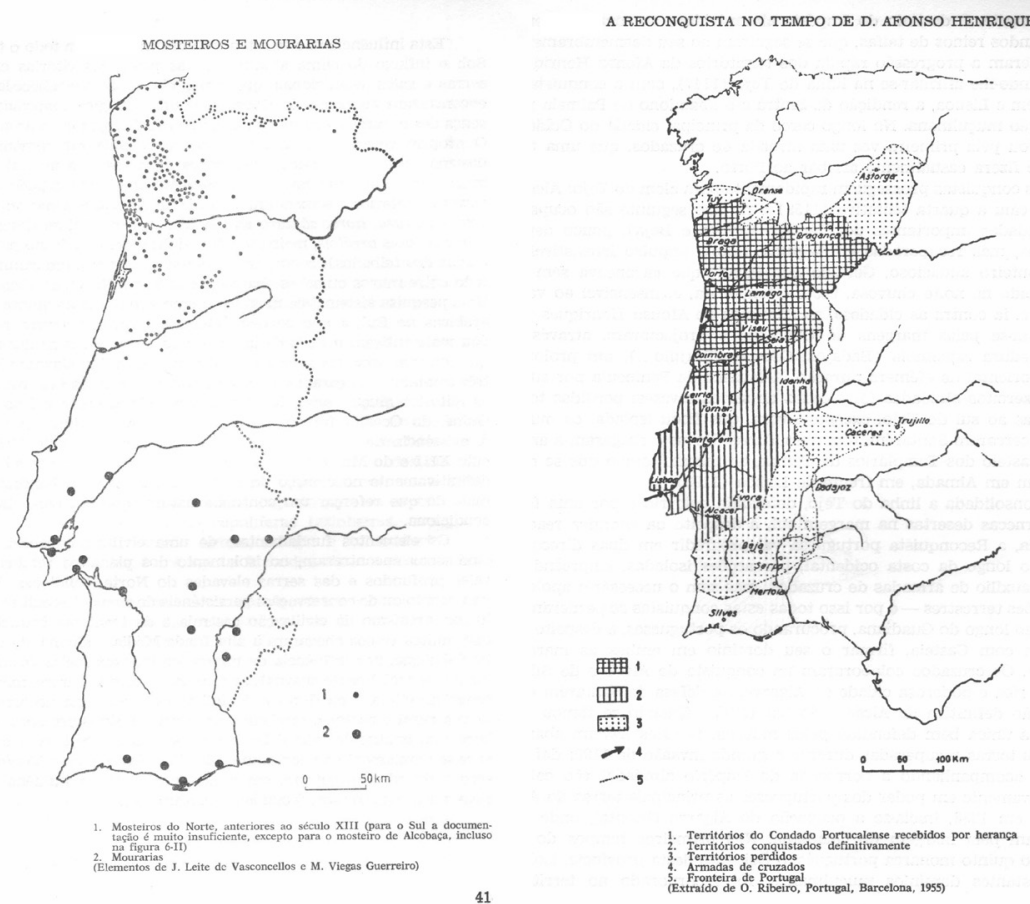

Estes instrumentos foram tocados por Cristãos, Mouros e Judeus, notando-se na iconografia e fontes escritas que alguns deles aparecem ligados a uma das comunidades, o que talvez explique o seu progressivo desaparecimento com a expulsão de Mouros e Judeus ordenada por D. Manuel I ( | 469-152 I) em 1496, caso não se convertessem à fé cristã. As perseguições de que foram alvo os conversos ou cristãos-novos e os mouriscos, designações dadas a todos os que foram forçados a aceitar o baptismo, marcam o início de um período de intolerância religiosa que iria culminar com a instauração, em Portugal, do tribunal do Santo Ofício por bula de 1547, no reinado de D. João III (1502-1557). 
Os primeiros cativos negros tinham chegado a Portugal em 1441. Na $2^{\circledR}$ metade do séc. XV chegaram ainda a Portugal os Ciganos que também seriam alvo de proibições de entrada no reino e mesmo ordem de expulsão em 1526 (Torres, 1979) ${ }^{14}$. A $1^{10}$ referência literária a Ciganos é a Farsa das Ciganas de Gil Vicente, talvez representada na Páscoa de 1525.

\section{A RECONQUISTA APOS D. AFONSO HENRIQUES}

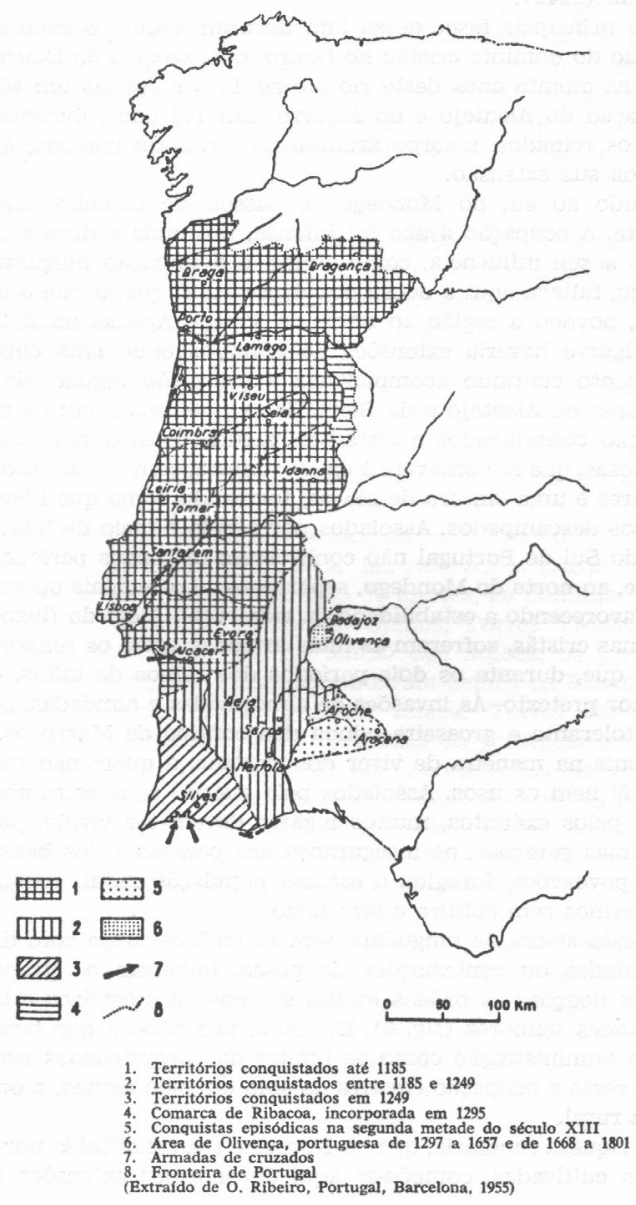

14 TORRES, R.A. - 'Ciganos' in Dic.Hist.Port. op.cit. 
Em 1535 o humanista Clenardo escrevia: "Os escravos pululam por toda a parte. Todo o serviço é feito por negros e mouros cativos". Avalia-se em cerca de 10.000 o número de escravos em Lisboa, em 1551, num total de 100.000 habitantes (Miguel, 1979) ${ }^{15}$.

Do ambiente cultural e musical no início da Expansão, é revelador o relato dos esponsais da Infanta D. Leonor, irmã de D. Afonso V (| 432-|48|), com o Imperador Frederico III da Alemanha, em |451, representado nas festas e cerimónias pelos seus embaixadores. Um deles, Lanckmann, diz-nos:

- "Vieram depois os etiopes e mouros, com artifício à maneira de dragão, e com danças e outros aparatos, fazendo reverência à Imperatriz"....)

- "No $15^{\circ}$ dia do mês de Outubro, o sereníssimo rei de Portugal mandou fazer muitas danças na Praça fronteira ao Palácio da Senhora Imperatriz".(...)

- "No $17^{\circ}$ dia do mês de Outubro, logo de madrugada, antes do nascer do Sol, vieram de uma parte cristãos, de outra parte sarracenos, de outra selvagens e de outra ainda judeus, e cada um destes bandos cantava, gritava e foliava na sua própria língua e maneira".

- "No $20^{\circ}$ dia do mês de Outubro, antes do nascer do Sol, vieram a esta praça turmas de gentes de um e outro sexo, de diversas línguas e nações, em folgares e danças diversas".

- "No $23^{\circ}$ dia, veio muito povo defronte do palácio da senhora Imperatriz Esposa, com diversos instrumentos músicos - tubas, buzinas, etc, - e dividiu-se em quatro troços: o primeiro de cristãos, de ambos os sexos, dançando à sua maneira; $\circ 2^{\circ}$, de mouros e mouras, também à sua maneira; $\circ 3^{\circ}$ de judeus de um e outro sexo, no seu costume; $04^{\circ}$ de mouros, etíopes e selvagens da llha Canária, onde os homens e mulheres andam nus, julgando serem e terem sido, assim, únicos no mundo".

15 MICUEL, S. - 'Escravatura' in Dic. Hist. Port. op. cit. 
As Festas do Império do Espírito Santo e a Procissão do Corpo de Deus, amplamente participadas pelo povo, e as sucessivas regulamentações de que são objecto nos sécs. XV e XVI, mostram-nos no entanto o conflito sempre presente entre os costumes populares e a igreja, que de há muito se sentia ameaçada pela persistência do que designava por "costumes gentios". A proibição das Janeiras e Maias no reinado de D. João I (1357-1433) daria mais tarde lugar a tentativas de canalizar as festas pagãs para o calendário religioso. As danças que se realizavam nos templos foram proibidas e transferidas para as procissões, alguns dos instrumentos musicais foram considerados impróprios de figurarem nas cerimónias religiosas e mesmo, é-nos permitido supor, de serem tocados por cristãos.

movimento da Contra-Reforma, de que a Inquisição e os Jesuítas são instituições fundamentais, instala-se em Portugal com a chegada dos Jesuítas em 1540 e o Tribunal do Santo Ofício em 1547. Os Jesuítas, principais obreiros das decisões do Concílio de Trento, ocupavam-se em Portugal da "pregação, exercícios espirituais, obras de caridade e, em especial, a instrução religiosa da juventude", e da evangelização e catequese nos territórios ultramarinos e no Oriente.

As primeiras levas de colonos são no entanto anteriores a esta acção evangelizadora e explicam de certo modo a sobrevivência dos antigos costumes e dos instrumentos musicais a elas ligados, por exemplo, nos Açores, com as Festas do Espírito Santo e no Brasil, pelo uso cerimonial da viola, também nas folias do Divino Espírito Santo.

Sabemos que até meados do séc. XVI, a música e os instrumentos musicais dos vários povos e culturas presentes na Península Ibérica se influenciaram mutuamente, conservando cada grupo as particularidades e identidade que lhes eram próprias, quando lhes era possivel, e adoptando de outros, mercê de condicionantes de ordem vária, o que melhor correspondia à necessária mudança e adaptação a novas situações. Com o movimento da contra-reforma, os instrumentos musicais portugueses, na sua forma e funções, vão-se restringindo ao que hoje encontramos no panorama musical português e em que as excepções, devidas ao isolamento de algumas regiões, no País e nos colonatos ultramarinos, nos confirmam que estamos em presença de dois momentos essencialmente diferentes da cultura portuguesa. Excepções que são sobrevivências, ou, em alguns casos, afirmação e resistência dos povos às proibições da igreja e do poder temporal. 
Crescimento da população a partir de 1450, que se manterá até ao final do séc. XVI é acompanhado por migrações internas do campo para a cidade e da montanha para a planície. Acentuam-se as áreas fundamentais que caracterizam, até aos nossos dias, o País, sob o ponto de vista cultural.

A música e os instrumentos populares resultantes das profundas modificações que Portugal vive, e que Gil Vicente tão bem descreve no Triunfo do Inverno ${ }^{16}$, lamentando o declínio da gaita de foles e do pandeiro nas terras ocidentais, onde "já não há hi gaita nem gaiteiro", permite-nos concluir que as particularidades das várias regiões estavam definidas no que de essencial as viria a caracterizar.

\section{Panorama Músico-Instrumental Popular Português - no séc. XIX / XX}

Ernesto Veiga de Oliveira no livro "Instrumentos Musicais Populares Portugueses" (1982)17:, obra fundamental para o estudo da Música Portuguesa, apoia-se na divisão que Orlando Ribeiro, em 1945, faz do País em Portugal Atlântico, Transmontano e Mediterrânico, atendendo primordialmente ao factor geográfico e às suas relações com o homem, embora não coincidente e focando um aspecto particular ${ }^{18}$ e que são "o planalto alto e leste transmontano e beirão, arcaizante e pastoril, fechado sobre si mesmo, e as terras baixas a ocidente da barreira serrana central, do Minho ao Tejo, populosas, conviventes, abertas a todas as influências; por fim a Sul do Tejo, o prolongamento do panorama pastoril do planalto e no Algarve condições semelhantes às que encontramos no Norte Litoral".

Mais do que na divisão do país em províncias, são nessas três grandes áreas que vamos encontrar, sob o ponto de vista musical, aspectos que as caracterizam e diferenciam. Parece-nos no entanto que só podemos falar de uma música regional se nos reportarmos a uma

\footnotetext{
16 Representada em Lisboa para celebrar o nascimento da Infanta Isabel, filha de D. João III, a $1^{\circ}$ de Abril de 1529.

17 OLIVEIRA, E.V.- Instrumentos Musicais Populares Portugueses, $2^{\circ}$ ed., Lisboa, 1982 ( $1^{10}$ edição 1966).

18 ibid., pp. 17-18.
} 
data anterior a 1950. Como nos diz Jorge Dias (1970) 19 “... até então, cada área cultural embora não estivesse inteiramente segregada do resto do país, vivia num relativo isolamento. Os transportes tradicionais, quando existiam, eram caros para as economias de subsistência". Os primeiros programas de rádio foram emitidos a partir de 1933 e nos anos 50 são lançados no mercado os primeiros rádios a preços acessivieis, a par com a electrificação das zonas rurais. A emigração e a guerra colonial (décadas de 60 e 70), a industrialização agrícola, trazem consigo profundas mudanças que alteram significativamente as ocasiões festivas, cerimoniais e de trabalho que davam significado à música das diferentes regiões.

Até meados do século XX as comunidades rurais quase que só dispunham, para todos os momentos da sua vida, de um repertório próprio, com instrumentos construídos por artífices locais, sendo as músicas aprendidas da tradição oral.

A salvaguarda desse património local, iniciado já nos anos 30 do séc. XX por Abel Viana, promotor do Rancho de Carreço (Minho), com o intuito de "preservar a música e a dança, criando grupos de jovens que se conservassem fiéis à tradição da sua terra", marca o início de uma nova época em que na sua maioria os Directores de Ranchos "inventaram eles próprios o seu repertório, desde o trajo fantasioso, até à música e à dança" 20 .

Os cortejos folclóricos, concursos, exibições nacionais e internacionais, foram decisivos para que mesmo as melhores intenções iniciais se fossem adulterando ${ }^{21}$, sendo muito recente, já dos anos 70, uma nova atitude de recriar a música e a dança nos Ranchos, que segundo Ernesto V. Oliveira ${ }^{22}$ deverão ter consciência do que fazem, quando querem fazer uma restituição de música ou dança de uma determinada época, o que não os impede de inventar novas danças e músicas, ligadas ou não à sua aldeia ou região, desde que não fantasiem, invocando falsas origens ou refugiando-se numa "autenticidade" que só faz sentido deste que datada e apoiada numa investigação sólida.

\footnotetext{
19 DIAS, António Jorge, Da música e da dança, como formas de expressão populares, aos ranchos folclóricos. pp.8-10. Lisboa, 1970.

20 lbid., p. 12.

21 Salwa El-Shawan Castelo-Branco E Jorge de Freitas Branco (eds.): Vozes do povo - A Folclorização em Portugal; Celta Editora, Oeiras 2003.

22 Numa comunicação, não-publicada, no Encontro de Ranchos Folclóricos Algarvios, em 1986.
} 


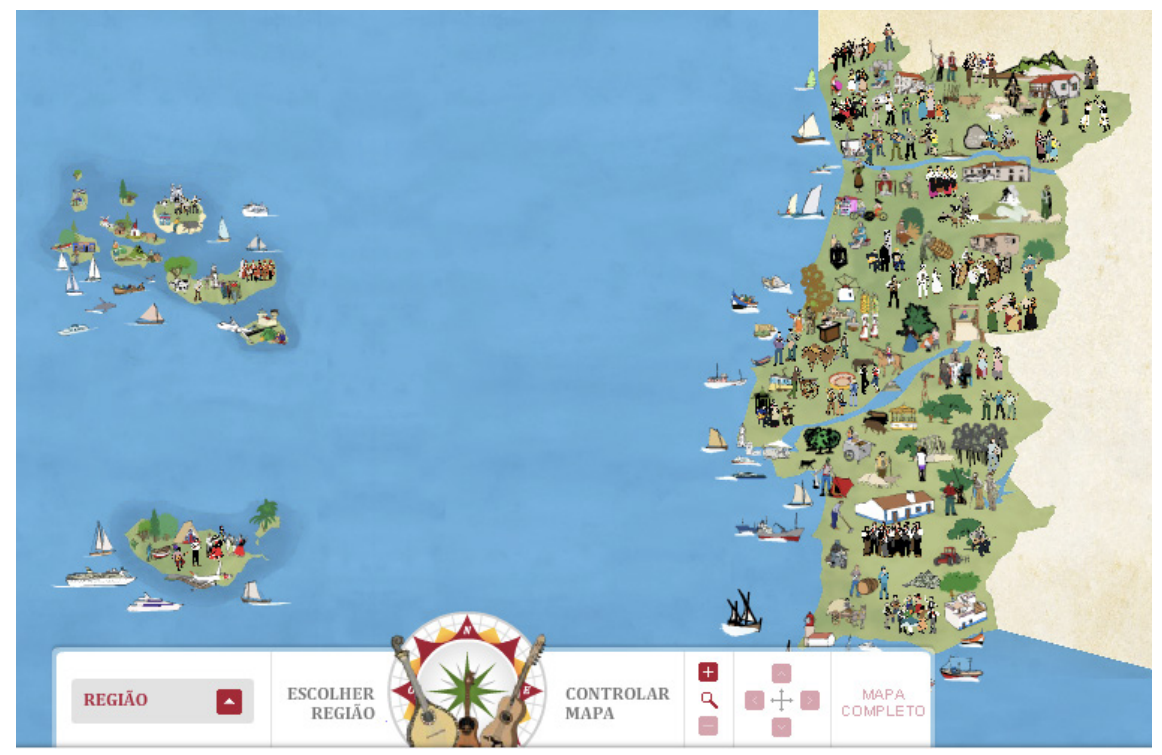

Mapa Etno-musical de Portugal ${ }^{23}$

\section{Violas em Portugal - uma longa história}

As violas portuguesas são os instrumentos mais disseminados em todo o território português, nas variantes eruditas e populares. A sua construção foi objecto de regulamentações que remontam ao séc. XVI e garantiam a certificação dos construtores. Por volta de 1551, a cidade de Lisboa dispunha de 16 violeiros - para uma população de cerca de 100.000 habitantes - distribuidos por sete "tendas", bem como varios fabricantes de cordas de viola (Cf. A viola de mão em Portugal) (Morais, Manuel 2006)24.

23 http://cvc.instituto-camoes.pt/conhecer/mapa-etno-musical.html.

$\bigcirc$ Centro Virtual Camões apresenta o Mapa Etno-Musical, um projecto que mostra a distribuição pelo território da música e dos instrumentos musicais característicos de cada região de Portugal, permitindo ainda ler a propósito textos explicativos e ouvir peças ilustrativas. O mapa é da autoria de Júlio Pereira, com a colaboração de João Luís Oliva e com o grafismo de Sara Nobre.

24 MORAIS, Manuel; "A viola de mão em Portugal (1450-1789)". Revista Aragoneza de Musicologia, vol. 22, n. I, 2006. 
Veiga de Oliveira 25 (Cf. Instrumentos Musicais Populares Portugueses) enumera e distingue nas violas populares portuguesas de cinco ordens a braguesa, a amarantina, a toeira, a beiroa (também designada bandurra beiroa) e a campaniça no Continente. E violas de arame ou violas da terra na Madeira e nos Açores. Estes instrumentos viajam para todas as partes do Mundo onde os portugueses se estabeleceram, com destaque para o Brasil e Cabo Verde.

Do tempo anterior aos registos magnéticos, é através da iconografia e pelo estudo de partituras a que temos acesso desde - séx. Xll que podemos reconstituir algumas das músicas populares portuguesas e os instrumentos nelas utilizados. Também nos arquivos dos tribunais religiosos (Inquisição) e na legislação ou proibições dos poderes seculares que na Península lbérica e na América Latina são das mais importantes fontes documentais disponiveis.

- conhecimento das práticas musicais no antigo Império Colonial Português e nas novas nações que dele nasceram teve um enorme desenvolvimento acessivel em publicações e teses académicas em Portugal e no Brasil. Em 2008, realizou-se em Lisboa o Colóquio Internacional As Músicas Luso-Brasileiras no Final do Antigo Regime: Repertórios, Práticas e Representações ${ }^{26}$, que organiza nas mais de 700 páginas em VII capítulos os temas Património, Individualidades, Contextos e representações, Práticas litúrgicas, Práticas teatrais e Práticas instrumentais.

Neste capítulo, Manuel Morais publica o estudo "A viola de arame no contexto português" (séculos XVIII-XX)", pp. 65 I-664. No Brasil, para apenas citar alguns dos estudos mais recentes, Ivan Vilela publica "Cantando a própria história"27, e Gisela Nogueira, "A viola com anima: uma construção simbólica"28. As ilustrações e fontes documentais bem

25 OLIVEIRA, Ernesto Veiga de, $1^{\circledR}$ edição: Lisboa 1964; $2^{\circledR}$ edição: Lisboa 1982; $3^{\circ}$ edição, Lisboa 2000.

26 As Músicas Luso-Brasileiras no Final do Antigo Regime: Repertórios, Práticas e Representações / org. Maria Elizabeth Lucas, Rui Vieira Nery. - Lisboa: Imprensa NacionalCasa da Moeda, 2012 (Lisboa: Imprensa Nacional-Casa da Moeda, 2012. - 721, [2] p. 27 VILELA, Ivan; Cantando a própria história: música caipira e enraizamento. São Paulo, 2013.

28 NOCUEIRA, Gisela, 2008; A viola com anima: uma construção simbólica. São Paulo, 2008. 
como a bibliografia consultada permitem conhecer em profundidade o percurso da viola de arame no Brasil desde os primeiros tempos da colonização.

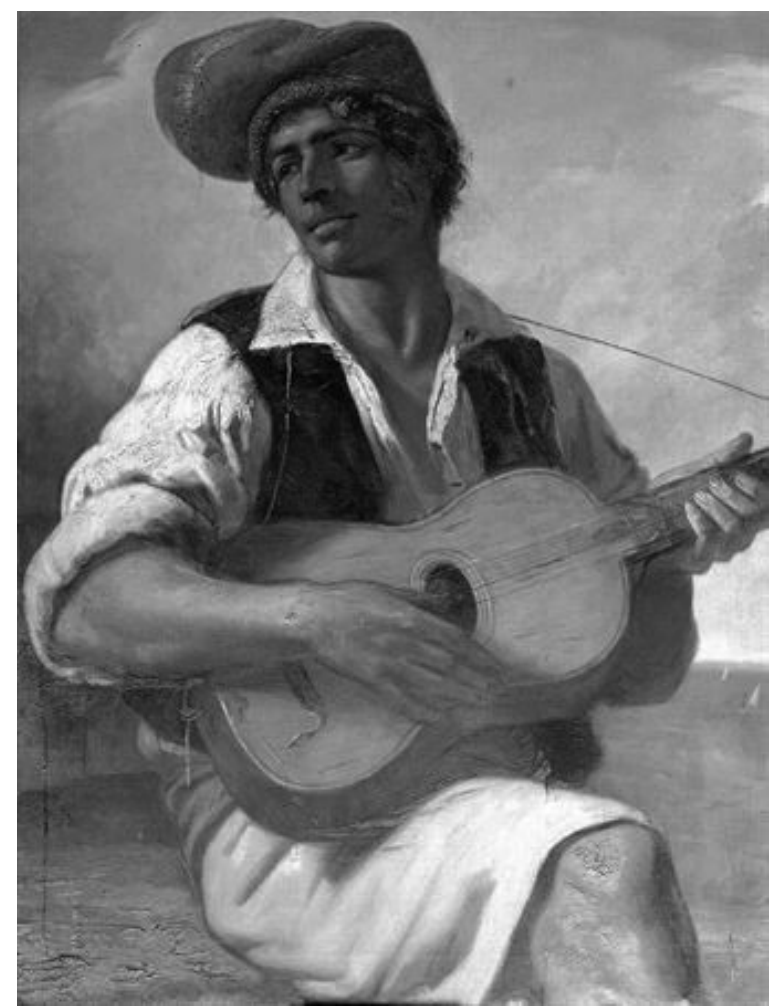

"Vareiro tocando Viola", Francisco José de Resende ${ }^{29}, 1866$.

As violas que mais nos importa conhecer, quer pela escassez de fontes documentais, quer pelos próprios instrumentos de que conhecemos raros exemplares de finais do séc. XVIII, são as que permaneceram nas comunidades rurais, tocando nas festas e cerimónias e se foram adaptando a novos contextos de utilização que explicam a diversidade organológica, de afinações e de procedimentos na transmissão de saberes e no seu reconhecimento pela comunidade próxima.

29 Museu do Chiado, Lisboa - Museu Nacional de Arte Contemporânea; Pintura a óleo, altura: 146; largura: 1 13; Pintura de costumes. Um pescador varino, de barrete na cabeça, camisa branca arregaçada e colete negro, pele queimada pelo sol, toca uma viola. 


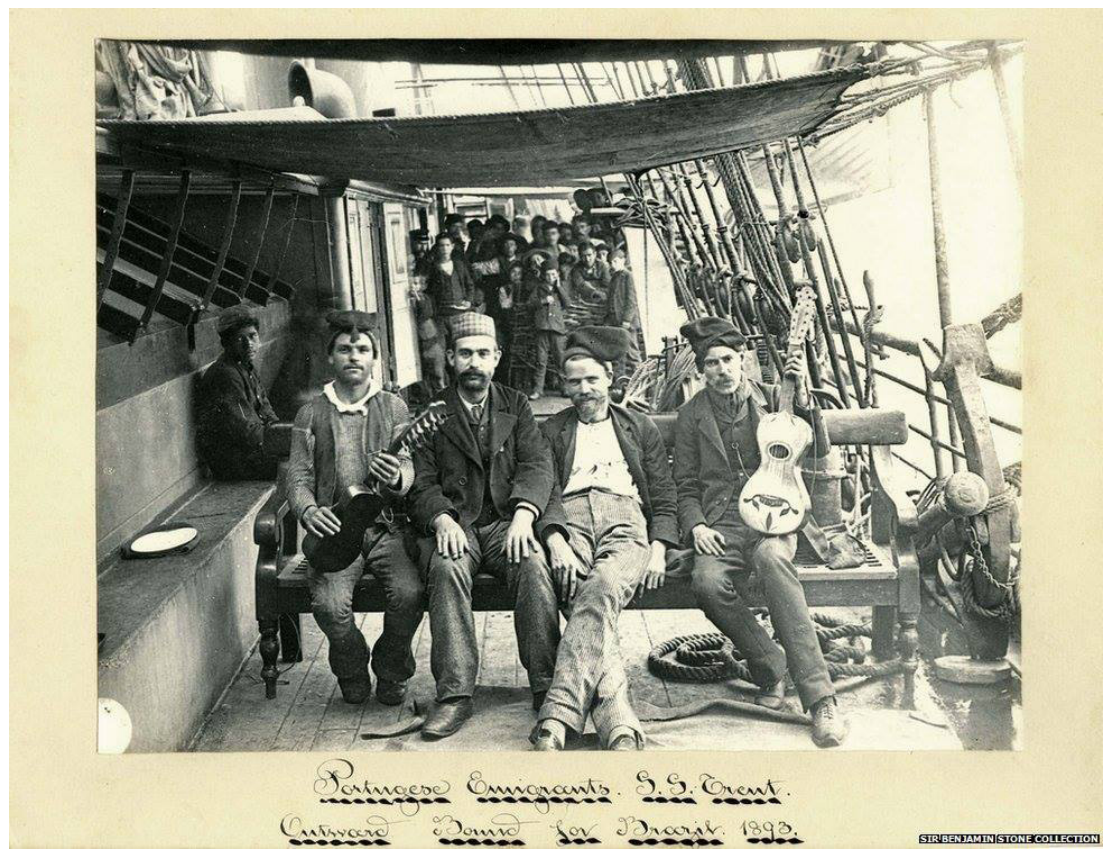

Viajaram na parca bagagem dos emigrantes ${ }^{30}$ que demandaram o novo Mundo sem saberem bem o que os esperava, fugindo de Portugal que dificilmente thes dava o sustento para os filhos e a esperança de construir um futuro.

Nos poucos haveres que juntavam para seu agasalho e para dar sentido à vida que deixavam para trás, encontramos instrumentos musicais. Os de corda e sopros, as percussões populares e um saber de séculos de como os construir, reparar, adaptar aos materiais que encontravam nas novas casas, aldeias e vilas que criavam.

Mas essa permanência e renovação na utilização de instrumentos musicais só foi possivel porque levavam consigo o que hoje sabermos ser a cultura imaterial, esse complexo de relações e conhecimentos transmitidos oralmente e que dão sentido à vida.

30 Emigrantes Portugueses partindo para o Brasil, 1893. Violas braguesas de 12 cordas de metal, cinco ordens ou parcelas $(3+3+2+2+2)$.

https://www.facebook.com/A-Viula-darame-em-Portugal- 157 109567652055 I/ 


\section{As Recolhas - ou os "sacos das cantigas"}

Almeida Carrett, com o seu Cancioneiro e Romanceiro Geral $(1843$ e 1851)31, terá sido o primeiro colector a reunir em publicação as jóias da tradição popular. Pelo sim, pelo não, ajeitou os textos e corrigiu particularismos regionais da língua. Antes dele, o Popular aparece em romances, ensaios, peças de teatro, poesias e músicas de autores que desde a ldade Média nos ajudaram a espreitar as culturas campesinas de que se serviram para as suas obras como os mestres de cozinha vão ao campo buscar sabores e aromas que thes agradam e servem os seus propósitos.

Sempre terá sido assim, por muito que disfarcem os abnegados colectores que com raras excepções reuniram os testemunhos imateriais e thes deram as arrumações que thes eram mais convenientes, de acordo com os procedimentos do seu tempo e na melhor das intenções. Sem o seu denodado esforço, teríamos ainda menos do que o pouco que temos. Infelizmente, parte dos acervos e publicações existentes em Portugal anteriores a 1755, foram destruidas pelo terramoto ocorrido nesse ano, nos incêndios que se the seguiram e muitos outros pela incúria e ignorância que também em Portugal são responsáveis pelo desaparecimento de documentos.

Do tempo anterior aos registos magnéticos, é pelos textos e também pelo estudo de partituras a que temos acesso desde o séc. XII que podemos reconstruir algumas das músicas populares portuguesas. Com os registos magnéticos (séc. XX, com Armando Leça ${ }^{32}$ nos anos 20 e Kurt Schindler ${ }^{33}$ nos anos 30) tudo mudaria. À semelhança da fotografia e do cinema mudo, os novos suportes de som permitiam o registo até aí impossivel de fonogramas que inicialmente apenas serviam para recordar e ajudar os colectores nas suas publicações e nas transcrições musicais. Os registos ficavam depois em caixas esquecidas que só muito mais tarde teriam direito a serem preservados e postos à disposição de quem o quisesse em edições discográficas.

31 GARRETT, Almeida J. B. de, 1843 e 1851, Cancioneiro e Romanceiro Geral, vol.I - 1843, vol.|l - |851, vol.|I - 1851.

32 LEÇA, Armando ( 1939/40), Recolhas musicais de Armando Leça a convite da Comissão Nacional para a Comemoração do Duplo Centenário, com o apoio técnico da Emissora Nacional (1939/40).

33 SCHINDLER, Kurt, Folk Music and Poetry of Spain and Portugal, 1941. 
Dois marcos fundamentais no reconhecimento do valor e interesse das recolhas: em 1945 a profunda influência exercida por Orlando Ribeiro como o seu "Portugal, o Mediterrâneo e o Atlântico" e a criação, em 1947, do Centro de Estudos de Etnologia Peninsular com Jorge Dias e a sua equipa de investigadores, em que Ernesto Veiga de Oliveira, Margot Dias e Manuel Viegas Guerreiro trarão contributos que mudam radicalmente o nosso conhecimento da música portuguesa. A par destes marcos, Artur Santos e Túlia Santos em 1956 publicam em disco algumas recolhas e Fernando Lopes Graça edita a sua "Canção Popular Portuguesa".

Esta descrição seria longa se quiséssemos fazer justiça a todos os que desde a década de 60 foram enchendo o "saco das cantigas". Mas com Francisco d' Orey e depois com Michel Giacometti inicia-se um novo caminho só possivel pelo começo das emissões de Televisão em 1957. Os recursos da televisão estatal são pela primeira vez utilizados na recolha de imagem e som utilizados depois em programas de cariz regionalista e raramente em documentários ou séries como excepcionalmente aconteceria nos anos 70 com o "Povo que Canta" de Michel Giacometti. Valerá a pena consultar a cronologia de Ana Carrapato $^{34}$ que me serve de guia nesta enumeração, infelizmente ainda inédita (As recolhas sonoras depois do 25 de Abril - Anexos).

E neste séc. XXI, para que nos servem essas centenas de horas de fonogramas e de videogramas que se acumulam em arquivos nem sempre acessiveis?

Para pouco, os que estão fechados a sete chaves, em instituições asilares da cultura como alguns Museus e Rádios, marinando à espera de um príncipe encantado que os desperte do seu longo sono.

Para muito, se o acesso for facilitado e aberto a TODOS os que tenham interesse (seja ele qual for) em os conhecer.

Reservem-se apenas, por mero decoro, utilizações menos próprias e abusivas ou claramente manipuladoras do ser e querer de quem deu os testemunhos (os únicos a meu ver que podem em última

34 CARRAPATO, Ana Sofia Gonçalves Almeida. As recolhas sonoras depois do 25 de Abri: Apropriações da música tradicional portuguesa. Um estudo de caso através dos Gaiteiros de Lisboa. Departamento de Antropologia do ISCTE. Lisboa, 2006. 
instância decidir do destino que thes deve ser dado). Mas deixe-se que o tempo esbata e revele o que a paixão do presente encobre, permitindo novas e fecundas leituras e utilizações.

A visibilidade das manifestações musicais populares para além das comunidades que lhes dão ou deram sentido, acontece muitas vezes de forma errática e incompreensivel, ao sabor do gosto e escolhas dos editores discográficos, dos programadores de eventos musicais e das comissões de festas, das direcções de programação da rádio e televisão. Quase todos se regem por critérios de ordem estritamente economicista, na dependência de estudos de mercado e de audiências, longe de preocupações de ordem cultural ou de serviço público. Por vezes nem há má vontade, apenas uma profunda ignorância e incapacidade na integração destes conteúdos numa programação equilibrada.

Mas mais grave é quando se utilizam as manifestações populares, desvirtuando-as, ao serviço de interesses editoriais ou de programações sem qualidade, contribuindo para a criação de estereótipos redutores em que mal se reconhecem os contextos originais. A apropriação turística, muitas vezes desvirtuando e mesmo alterando as festas e cerimónias populares é neste século XXI uma séria ameaça ao que cada cultura construiu num longo processo de adaptação e mudança vividos por cada comunidade.

Estamos em crer que é pela divulgação inteligente e informada de conteúdos, servida por suportes de grande qualidade que será possivel contrariar a presente dificuldade em romper os muros de ignorância, de silêncio e de indiferença.

acesso a acervos documentais multimédia tem tido um impressionante desenvolvimento, tendo em Portugal as principais Universidades e Institutos disponibilizado Teses e Estudos que permitem conhecer o que era quase inacessivel.

Alguns desses acervos são consultáveis nos seguintes endereços: 
IELT - Instituto de Estudos de Literatura e Tradição https://ielt.fcsh.unl.pt/pt/inicio

MEMORIA MEDIA

http://www.memoriamedia.net/

INET-MD - Instituto de Etnomusicologia - Música e Dança http://www.inetmd.pt/

MUSEU CAVAQUINHO

http://www.cavaquinhos.pt/pt/

MUSEU DO FADO

http://www.museudofado.pt/

POVO QUE CANTA (MICHEL CIACOMETTI, 197 I)

http://www.rtp.pt/programa/episodios/tv/p 16746

POVO QUE CANTA $2^{\circledR}$ SÉRIE (MANUEL ROCHA, 2009)

http://www.rtp.pt/programa/tv/p 18564

ARQUIVO SONORO DE ERNESTO VEIGA DE OLIVEIRA http://alfarrabio.di.uminho.pt/araevo/

MURAL SONORO

http://www.muralsonoro.com/

A MŨSICA PORTUCUESA A COSTAR DELA PRÓPRIA https://vimeo.com/mpagdp

DOMINCOS MORAIS - ARQUIVO DMUDR85

Músicas recolhidas em Trás-os-Montes e Lisboa

http://alfarrabio.di.uminho.pt/aradmurd85/

Domingos Morais - arquivo DMUDR87

Músicas recolhidas nos Açores

http://natura.di.uminho.pt/ARQEVO/index.dmurd87.html 


\section{Do gesto musical, gerador privilegiado de identidade cultural - ou de como se forma o sentimento de pertença consciente}

A música que hoje ouvimos (e mais raramente fazemos), parecenos talvez desligada de muitas das nobres funções e actividades que nos primórdios das comunidades humanas pontuavam a sobrevivência, a expansão lúdica e a vida ritual. A divisão operada no quotidiano da população activa entre tempo de trabalho e de não-trabalho, a par com a emergência de uma rentabilidade a todo o custo, afastaramnos de vez de actividades que decorriam ao ritmo das estações do ano e dos ciclos próprios da recolecção, da caça, da agricultura, pecuária, pesca e artesanato.

A música é utilizada nos locais de trabalho ou nas grandes superfícies comerciais com funções previstas de aumentar a produtividade, estimular o consumo, induzir estados de euforia e de diminuição das capacidades de auto controlo.

Música e gesto musical que entendemos como ${ }^{35}$ :

Música: universo significativo de sonoridades e estruturas sonoras, reconhecido como tal por um determinado grupo humano, habitualmente ligadas a procedimentos e instrumentos próprios.

Gesto musical: mobilização e domínio do corpo enquanto gerador de música. A sua aquisição consegue-se pela observação, imitação, experimentação e reinvenção, permitindo o desenvolvimento de capacidades vocais e corporais, o domínio de instrumentos, o movimento e a dança.

As situações novas em que homens e mulheres desenvolvem a sua actividade profissional teriam também muito a lucrar se algumas das formas próprias desenvolvidas pela espécie ao ligar a música (e a dança) ao trabalho não fossem esquecidas, sendo substituídas por subprodutos musicais, manipuladores e entorpecentes da vontade e do prazer. $\bigcirc$ balanço necessário entre realização pessoal, bem estar

35 MORAIS, Domingos (2001). - "Identidade Cultural, ou de como se forma o sentimento de pertença" in A Cultura no século XXI. Santiago de Compostela, 5 de Maio de 2001. 
e afirmação cultural contrapostos a produtividade e rentabilidade necessitam de ser repensados nas sociedades que defendendo teoricamente valores e direitos têm dificuldade em os tornar efectivos nos locais de trabalho modernos.

Permito-me assim lançar algumas questões:

(Quais são:) $\bigcirc$ tempo e os espaços adequados ao desenvolvimento da identidade músico/gestual

(Quem podem ser:) Os transmissores e aferidores das competências músico/gestuais

(Haverá contradição entre:) A expressão pessoal e a norma cultural músico/gestual

(Como se desenvolve o:) Sentimento de pertença e desenvolvimento progressivo da capacidade de assumir papéis músico/ gestuais e de dança na comunidade

(Como se desenvolve a:) Capacidade de aceitação da mudança nos referentes culturais próprios, de integração de influências externas, de abertura a outros modos de expressão de outros grupos culturais

(Como se desenvolve a:) Capacidade de inovação e de assumir papéis de transmissor/aferidor na comunidade

Fernando Lopes Graça (1906-1994) é o músico e compositor que melhor terá pensado e feito obra que de certo modo responde às questões colocadas. Esse propósito foi concretizado num impressionante catálogo que reúne o conjunto dos autógrafos musicais de Fernando Lopes-Graça, totalizando 260 títulos e 694 peças entre obras válidas, versões, revisões, esboços e transcrições. $\bigcirc$ Museu da Música Portuguesa, no Estoril, Cascais, guarda o acervo oferecido pelo compositor e promove a divulgação da sua obra numa página que the é dedicada 36 .

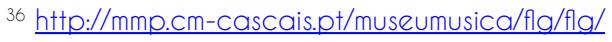


As canções que ides ouvir roubei-as eu ao nosso povo, que tem um grande tesouro delas: e roubei-lhas, não para as guardar para mim, mas com o propósito de lhas restituir, possivelmente com juro do roubo. Mandam a lei e os bons costumes que não fiquemos com os bens dos outros, mesmo quando os outros possuem tesouros. Ora, como as canções são um dos raros e preciosos bens do povo português, eu sentiria a consciência pesar-me se, apropriando-me delas, lhas não restituísse. Não lhas restituo, porém, tal-qualmente thas roubei: fiquei com alguma coisa delas e, ao devolverthas, procurei que elas não ficassem diminuidas no seu valor, antes diligenciei aumentá-las com aquele pequeno juro que está nas minhas posses despender. ${ }^{37}$

Também Michel Giacometti (1929-1990) a quem se deve a mais extensa e completa recolha de música portuguesa realizada até cerca de 1980, tem uma página neste Museu que foi obra sua ao receber a colecção de instrumentos populares portugueses do investigador e a sua biblioteca, além de um valioso espólio de imagens e inéditos cuja publicação está em curso ${ }^{38}$.

Em 1981 Michel Giacometti e Fernando Lopes-Graça publicam o "Cancioneiro Popular Português" que reúne 250 partituras seleccionadas dos mais importantes colectores numa edição de 20.000 exemplares, a maior de sempre para uma obra dedicada a este tema.

Uma outra colectânea de melodias e canções portuguesas organizada por Alexandre Wefford em $2006^{39}$ revela muitas das fontes utilizadas por Lopes-Graça nas suas obras. São 150 textos musicais num livro e CD ROM que inclui ainda os textos do compositor sobre o folclore e a música popular portuguesa.

Estas e outras fontes são hoje procuradas por muitos músicos profissionais e amadores. As edições discográficas e videográficas

\footnotetext{
37 Introdução a um concerto (1956?) do Coro da Academia de Amadores de Música (Secção de Folclore), realizado no Tivoli, de Lisboa, por iniciativa da Juventude Musical Portuguesa [Nota de F. Lopes-Graça].

38 http://mmp.cm-cascais.pt/museumusica/mg/

39 UEFFORT, Alexandre Branco. A canção popular portuguesa em Fernando Lopes Graça. Editorial Caminho, Lisboa, 2006.
} 
esgotam e são depois copiadas e passadas de mão em mão (ou entre computadores). A música e a dança de raiz popular, reinventada em novos contextos movimenta milhares de praticantes em Festivais por todo o Pais. Lia Marchi (2006) percorreu o Pais durante dois anos, como bolseira da Fundação Gulbenkian, tendo publicado com o apoio do Instituto de Estudos de Literatura Tradicional (IELT) da Universidade Nova de Lisboa um "breve guia bibliográfico, sonoro e de websites, de Portugal e do Brasil" revelador desse interesse 40 .

\section{Sobre o autor}

Domingos Morais. Escola Superior de Teatro e Cinema do Instituto Politécnico de Lisboa. Autor de livros e artigos sobre educação artística, etnomusicologia e desenvolvimento curricular e de música para cinema, teatro e televisão. Foi professor na Escola Superior de Teatro e Cinema. É membro do IELT, Instituto de Estudos de Literatura Tradicional da Universidade Nova de Lisboa e consultor da Cooperativa de Educação e Ensino "A Torre". Consultor da Fundação Calouste Gulbenkian para Projectos de desenvolvimento curricular.

40 MARCHI, Lia; Tocadores Portugal - Brasil / Sons em movimento. Curitiba, 2006, pp. 113-123. 


\section{Reconhecimento Internacional dos Direitos Humanos e de salvaguarda da Cultura Popular}

Não seria possivel realizar com isenção os estudos e a promoção da cultura popular sem os novos quadros de referência ética decorrentes da criação de instituições internacionais (ONU, UNESCO) com capacidade e poder de mobilização das Nações através de recomendações e convénios para novos paradigmas respeitadores da diversidade cultural e do respeito pela dignidade da vida de todos os Homens e Mulheres.

É ainda no decorrer da $2^{a}$ guerra mundial, na década de 40 do séc. XX que se enunciam princípios que mudariam os quadros de referência da actividade social e política e se penalizam ou estigmatizam quem persiste em não respeitar os mais elementares Direitos humanos. A condenação do racismo em 1950, e os Direitos da Criança em 1959, estão entre os que viriam a promover mudanças profundas em todo o Mundo.

Merecem destaque, no que importa nomeadamente ao conhecimento das práticas musicais populares os seguintes, entre outros:

- RECOMENDACÃO RELATIVA À PARTICIPACÃO E CONTRIBUICÃO DAS MASSAS POPULARES NA VIDA CULTURAL (NAIROBI) - UNESCO 1976

- DECLARACÃO UNIVERSAL SOBRE A DIVERSIDADE CULTURAL UNESCO 2002

conhecimento destes documentos e a sua aplicabilidade ou recusa por alguns países constitui matéria obrigatória para quem pretende conhecer e participar na criação cultural contemporânea.

Não dispensando a leitura dos textos completos, disponíveis nas páginas da UNESCO, na Internet, transcrevemos alguns excertos que nos parecem de enorme actualidade:

Recomendação relativa à participação e contribuicão das massas populares na vida cultural (Nairobi, Novembro de 1976)

Recordando que a Constituição da UNESCO, no seu preâmbulo, declara que, para a dignidade do Homem são indispensáveis "a ampla difusão da cultura e a educação da humanidade para a Justiça, a Liberdade e a Paz". 
(...)

\section{Considerando}

(...)

c) que a cultura deixou de ser unicamente uma acumulação de obras e conhecimentos que uma elite produz, compila e conserva com o fim de colocá-las ao alcance de todos; ou o que um povo enriquecido pelo seu património oferece a outros como modelo do que a história os haja privado; que a cultura não se limita ao acesso às obras de arte e às humanidades, mas é simultaneamente a aquisição de conhecimentos, exigência de um modo de vida e necessidade de comunicação.

(...)

Observando que a acção cultural, por vezes, só afecta uma parte mínima da população e que apesar das organizações existentes e dos meios utilizados nem sempre corresponde às necessidades de quem se encontra numa posição extremamente vulnerável devido a uma educação insuficiente, baixo nível de vida, meio ambiente medíocre e, em geral, dependência económica e social;

(...)

Consciente da responsabilidade que incumbe aos Estados Membros de incrementar políticas culturais que permitam alcançar os objectivos enunciados na Carta das Nações Unidas, Constituição da UNESCO, Pacto Internacional de Direitos Económicos, Sociais e Culturais e a Declaração de Princípios da Cooperação Cultural Internacional;

(...)

Considerando que o objectivo último do acesso e da participação elevar o nível espiritual e cultural de toda a sociedade, com base nos valores humanísticos, e dar à cultura um conteúdo democrático humanitário, o que por sua vez pressupõe adoptar medidas de combater a influência perniciosa da "cultura comercial de massas" que ameaça as culturas nacionais e o desenvolvimento cultural da humanidade, conduz ao envilecimento pa personalidade e sobretudo influência de maneira nefasta a juventude;

(...) 


\section{Definič̃es e campo de aplicação}

I A presente Recomendação concerne ao conjunto de esforços que seria conveniente os Estados Membros ou as autoridades empreendessem para democratizar os meios e instrumentos de acção cultural, afim de que todos os indivíduos possam participar plena e livremente na criação da cultura e nos seus benefícios, de acordo com as exigências do progresso social.

2. Para os efeitos da presente recomendação:

a) entende-se por acesso à cultura a possibilidade efectiva para todos, principalmente por meio da criação de condições socioeconómicas, de informar-se, formar-se, conhecer, compreender livremente e desfrutar dos valores e bens culturais;

b) entende-se por participação na vida cultural a possibilidade efectiva e garantida para todo o grupo, de o indivíduo expressarse, comunicar, actuar e criar livremente, com o objectivo de assegurar o seu próprio desenvolvimento, uma vida harmoniosa e o progresso cultural da sociedade;

\section{DECLARAÇÃO UNIVERSAL SOBRE A DIVERSIDADE CULTURAL - UNESCO 2002}

IDENTIDADE, DIVERSIDADE E PLURALISMO

Artigo $1^{10}$

- A diversidade cultural, patrimônio comum da humanidade

A cultura adquire formas diversas através do tempo e do espaço. Essa diversidade se manifesta na originalidade e na pluralidade de identidades que caracterizam os grupos e as sociedades que compõem a humanidade. Fonte de intercâmbios, de inovação e de criatividade, a diversidade cultural é, para o gênero humano, tão necessária como a diversidade biológica para a natureza. Nesse sentido, constitui o patrimônio comum da humanidade e deve ser reconhecida e consolidada em beneficio das gerações presentes e futuras. 